\title{
Evaluation of Czech hop varieties
}

\author{
Vladimír Nesvadba ${ }^{*}$, Jana Olšovská ${ }^{2}$, Lenka Straková ${ }^{3}$, Jitka Charvátová ${ }^{1}$ \\ ${ }^{1}$ Hop Research Institute Co., Ltd., Žatec, \\ Kadaňská 2525, 43801 Žatec, Czech Republic \\ 2 Research Institute of Brewing and Malting, \\ Lípová 15, 12044 Prague, Czech Republic \\ ${ }^{3}$ Mendel University in Brno, Faculty of AgriSciences, \\ Zemědělská 1, 61300 Brno, Czech Republic \\ *corresponding author: nesvadba@chizatec.cz
}

\begin{abstract}
Czech hop varieties are evaluated as part of maintenance breeding. Every year, this evaluation includes ten mother plants of each hop variety. Yield is determined in kilograms of fresh hops per plant. The t-test is used to determine significance. Results from the years 2014-2019 show that Gaia and Kazbek have the highest yield (3.17 kg/plant and $3.05 \mathrm{~kg} /$ plant, respectively). Their yield is higher than that of the Harmonie, Agnus, Bohemie, Premiant, Sládek, Boomerang and Saaz varieties. Saaz has the lowest hop yield, i.e. 1.85 kg/plant. Bor, Saaz Late, Saaz and Sládek show the lowest variability, which ranges between 20.56 and 20.58\%. Gaia has the highest variability (34.33\%). Gaia also has the highest alpha acid content (12.30\%) with a probability of $95 \%$ to $99 \%$. Vital and Boomerang have a higher alpha acid content than other Czech hop varieties (11.09\% and $10.81 \%$, respectively) with a probability of $99 \%$. Saaz Late (3.42\%) and Saaz (3.06\%) have the lowest alpha acid content with a probability of $95 \%$ to $99 \%$. The variability of alpha acid content is considerably lower than the hop yield variability. Rubín has the lowest year-on-year variability of all Czech varieties (4.81\%). Vital and Gaia have a very low variability (5.63\% and 5.72\%, respectively). A higher variability of alpha acid content was found in Saaz Late, Premiant, Agnus, Saaz, Kazbek, Bor and Harmonie, ranging between $8.01 \%$ and $10.21 \%$.
\end{abstract}

Keywords: hop, Humulus lupulus L., yield, alpha acids, variability

\section{Introduction}

Hop breeding in the Czech Republic has a long tradition. Currently, the Hop Research Institute in Žatec registers 20 hop varieties. The first clone selection was carried out in the Auscha population by Kryštof Semš of Vrbice near Roudnice, who made a positive selection in his hop vegetation. Associate professor Karel Osvald was the founder of modern methods of hop breeding based on clone selection in original regional vegetation. He had been involved in clone selection from 1927. Thanks to his long-term efforts, Czech hop growing gained three clones named after this breeder. Currently, Saaz takes up 90\% of the Czech Republic's total hop acreage (Fric, 1992). In the 1960s, hop hybridisation was introduced to hop breeding. In 1994, Bor and Sládek became the first registered Czech hop varieties resulting from hybridisation.
cIn 1996, Premiant was registered as a new hop variety, replacing Bor thanks to higher performance parameters. In 2001, the first Czech variety of bittering hops was registered (Agnus), showing an alpha acid content of $10 \%$ (Nesvadba et al., 2002). Between 2004 and 2010, the Hop Research Institute registered six additional hop varieties (Nesvadba et al., 2013) - Harmonie (2004), Rubín (2007), Vital (2008) - the breeding of which was also aimed at biomedical applications (Krofta et al., 2013) Kazbek (2008), Bohemie (2010) and Saaz Late (2010). Since 2017, a new generation of hop varieties has been registered. In 2017, two new bittering hop varieties, Gaia and Boomerang, were registered (Nesvadba et al., 2017), followed by the Saaz Brilliant, Saaz Comfort, Saaz Shine and Mimosa aroma hop varieties in 2019 (Nesvadba et 
al., 2019a). It is also necessary to mention the breeding of hops for low trellises (Nesvadba, 2016) and the registration of the first Czech hop varieties for low-trellis production (Country, Jazz and Blues) in the years 2018 and 2019 (Nesvadba, 2020).

Currently, the stability of qualitative and quantitative characteristics is being addressed. Performance stability is very important both for hop growing and beer brewing. In 2021, project QK21010136 entitled Application of new hop varieties and genotypes resistant to drought in hop growing and beer brewing was launched. Its objective is to test the stability of required characteristics in existing hop varieties. Stability suggests good resistance to external influences, including drought resistance. The second relevant objective is the testing of Czech hop varieties in terms of resistance to Verticillium nonalfalfae within the EUREKA LTE218 project entitled Creation of genotypes of hops resistant to Verticillium nonalfalfae suitable for growing both in the Czech Republic and within the European Union. Partial results show a medium resistance of the Agnus, Gaia, Kazbek and Sládek hop varieties. Therefore, performance of these hop varieties is being monitored.

Based on their application in beer brewing, hop varieties are divided into aroma and bittering hops. Hop varieties must always meet the required parameters of resistance to fungal disease, agrotechnical aspects (length of vegetation period, pickability of hops, strength of hop cones etc.), storability, high yield as well as the necessary content of resins (Čereniak, 2015). Hop varieties are grown for at least 10 years, and therefore emphasis is being put on the stability of yield and alpha acid content. All registered hop varieties are being monitored in terms of stability and uniformity as part of maintenance breeding. The origin of hop varieties is tested by DNA analyses (Patzak, 2018). Maintenance breeding is the basis for selecting mother plants for revitalization as well as for the preparation of a virus-free planting stock for hop growers.

\section{Material and methods}

The evaluation of performance focused on genotypes suitable for high trellises was part of hop maintenance breeding, which includes original mother plants and not revitalized plants. Therefore, the performance of some hop varieties may be lower than that of vegetation resulting from a virus-free planting stock (Svoboda et al., 2013). All hop varieties in maintenance breeding are located in a single hop field. A minimum of 40 plants of each hop variety is monitored and 10 mother plants are evaluated per year. The evaluation of mother plants focuses on morphological characteristics, while analysing deviations from uniformity of the hop variety. Each mother plant is evaluated in terms of hop yield and alpha acid content (EBC 7.4 described in Krofta, 2008). Dry hop cones are subject to mechanical analyses. Every plant is harvested separately. A Volf pilot picking machine is used for hop picking. Yield is specified in kilograms of fresh hops per plant (hereinafter referred to as $\mathrm{kg} /$ plant). Conversion of hop yield is based on the number of plants per hectare, which corresponds to 2,900 plants at a spacing of $1.14 \times 300 \mathrm{~m}$. The coefficient of dry substance in fresh hops/dry hops amounts to 4 .

Basic statistics of average and variations coefficients were prepared. The latter, expressed as percentage, characterises variability. A significance of difference between hop varieties was determined by the t-test.

\section{Results and discussion}

Gaia has the highest yield, amounting to $3.17 \mathrm{~kg} / \mathrm{plant}$ (Table 1). This value can be converted to $2.3 \mathrm{t} / \mathrm{h}$. The Kazbek variety shows a hop yield of above $3 \mathrm{~kg} /$ plant as well. Both varieties have significantly higher yields than the varieties with yields of less than $2.61 \mathrm{~kg} /$ plant, which are the varieties listed below Saaz Late. Based on the statistical significance determined by the t-test, the entire set of hop varieties can be divided into three parts (Table 2). Gaia, Kazbek, Vital, Bor, Rubín and Saaz Late are the highest-yielding hop varieties. The second group consists of Harmonie, Agnus, Bohemie, Premiant, Sládek and Boomerang. The hop varieties falling into this group provide good yields as well, which is very important both for hop growing and beer brewing. Saaz has the significantly lowest yield. From the hop varieties tolerant to Verticillium nonalfalfae, Kazbek and Vital have considerably higher yields than Agnus and Sládek. 
Table 1 Average hop yield (kg/plant) of Czech hop varieties in the years 2014-2019

\begin{tabular}{|c|c|c|c|c|c|c|c|}
\hline Variety & 2014 & 2015 & 2016 & 2017 & 2018 & 2019 & Average \\
\hline Gaia & 3.59 & 2.70 & 3.34 & 4.09 & 2.63 & 2.67 & 3.17 \\
\hline Kazbek & 3.19 & 2.81 & 2.95 & 3.11 & 2.64 & 3.61 & 3.05 \\
\hline Vital & 2.39 & 2.81 & 2.62 & 2.87 & 3.13 & 3.98 & 2.97 \\
\hline Bor & 2.65 & 2.61 & 3.22 & 3.31 & 2.49 & 3.01 & 2.88 \\
\hline Rubín & 3.41 & 2.75 & 2.90 & 2.13 & 2.96 & 3.00 & 2.86 \\
\hline Saaz Late & 3.50 & 2.15 & 2.24 & 2.64 & 2.19 & 3.67 & 2.73 \\
\hline Harmonie & 3.15 & 2.21 & 2.46 & 2.11 & 2.67 & 3.06 & 2.61 \\
\hline Agnus & 2.85 & 2.03 & 1.77 & 2.56 & 3.29 & 3.11 & 2.60 \\
\hline Bohemie & 3.28 & 2.52 & 2.20 & 2.76 & 2.21 & 2.35 & 2.55 \\
\hline Premiant & 2.93 & 2.17 & 2.34 & 2.61 & 2.39 & 2.09 & 2.42 \\
\hline Sládek & 2.61 & 1.89 & 3.00 & 1.95 & 2.41 & 2.52 & 2.40 \\
\hline Boomerang & 1.63 & 2.35 & 2.19 & 2.76 & 2.28 & 2.95 & 2.36 \\
\hline Saaz & 1.70 & 2.11 & 2.38 & 1.55 & 1.00 & 2.34 & 1.85 \\
\hline
\end{tabular}

Table 2 Significance of difference in hop yield between hop varieties determined by the t-test

\begin{tabular}{|c|c|c|c|c|c|c|c|c|c|c|c|c|}
\hline Variety & Gaia & & & & & & & & & & & \\
\hline Kazbek & - & K & & & & & & & & & & \\
\hline Vital & - & - & v & & & & & & & & & \\
\hline Bor & - & - & - & B & & & & & & & & \\
\hline Rubín & - & - & - & - & $\mathbf{R}$ & & & & & & & \\
\hline Saaz Late & - & - & - & - & - & $S L$ & & & & & & \\
\hline Harmonie & 0.1 & 0.05 & - & - & - & - & H & & & & & \\
\hline Agnus & 0.1 & 0.10 & 0.1 & - & - & - & - & $A$ & & & & \\
\hline Bohemie & 0.1 & 0.05 & 0.1 & - & - & - & - & - & B & & & \\
\hline Premiant & 0.01 & 0.05 & 0.1 & 0.05 & 0.05 & - & - & - & - & $P$ & & \\
\hline Sládek & 0.05 & 0.05 & 0.1 & 0.05 & 0.05 & - & - & - & - & - & SI & \\
\hline Boomerang & 0.05 & 0.01 & 0.01 & 0.05 & 0.1 & - & - & - & - & - & - & B \\
\hline Saaz & 0.05 & 0.01 & 0.01 & 0.01 & 0.01 & 0.05 & 0.05 & 0.1 & 0.05 & 0.10 & 0.1 & 0.1 \\
\hline
\end{tabular}

The Bor and Saaz Late varieties show the lowest variability of hop yield (Table 3). Only Boomerang had a variability of hop yield below $10 \%$ in 2015. In contrast, Gaia shows the highest variability, which was nearly $50 \%$ in 2018. Unfortunately, the Gaia variety is not suitable for a long-term hop cultivation. Its variability of alpha acid content leads to uncertainty in hop production. Based on variability determined by the t-test, the hop varieties can be once again divided into three groups (Table 4). The lowest variability was found in Bor, Saaz Late, Saaz and Sládek. The second group consists of Boomerang, Vital, Kazbek, Bohemie, Harmonie, Rubín, Premiant and Agnus, which have a variability ranging between $23.26 \%$ and $28.97 \%$. Gaia has the significantly highest variability. Among hop varieties tolerant to Verticillium nonalfalfae, Sládek has a notably lower hop yield variability than Vital, Kazbek and Agnus. 
Table 3 Average variability (\%) of hop yield in the years 2014-2019

\begin{tabular}{|c|c|c|c|c|c|c|c|}
\hline Variety & 2014 & 2015 & 2016 & 2017 & 2018 & 2019 & Average \\
\hline Bor & 21.96 & 27.81 & 22.56 & 16.93 & 15.31 & 18.79 & 20.56 \\
\hline Saaz Late & 27.71 & 16.72 & 13.97 & 25.70 & 15.38 & 24.38 & 20.65 \\
\hline Saaz & 20.17 & 21.05 & 20.08 & 28.66 & 20.45 & 20.85 & $\mathbf{2 1 . 8 8}$ \\
\hline Sládek & 18.08 & 12.09 & 21.53 & 26.43 & 30.23 & 27.08 & $\mathbf{2 2 . 5 8}$ \\
\hline Boomerang & 34.13 & 9.10 & 26.65 & 23.88 & 25.55 & 20.26 & $\mathbf{2 3 . 2 6}$ \\
\hline Vital & 27.63 & 14.50 & 15.73 & 34.76 & 21.87 & 27.43 & 23.66 \\
\hline Kazbek & 32.90 & 20.00 & 33.51 & 23.60 & 30.73 & 20.16 & 26.82 \\
\hline Bohemie & 36.32 & 21.83 & 32.16 & 22.53 & 33.46 & 20.56 & 27.81 \\
\hline Harmonie & 22.39 & 25.02 & 28.71 & 30.05 & 37.94 & 23.93 & 28.01 \\
\hline Rubín & 27.54 & 28.89 & 38.38 & 25.32 & 26.62 & 23.35 & $\mathbf{2 8 . 3 5}$ \\
\hline Premiant & 21.34 & 29.59 & 37.10 & 31.67 & 26.96 & 24.26 & $\mathbf{2 8 . 4 9}$ \\
\hline Agnus & 39.85 & 31.34 & 17.97 & 32.47 & 26.94 & 25.27 & $\mathbf{2 8 . 9 7}$ \\
\hline Gaia & 33.45 & 29.88 & 35.79 & 27.72 & 48.94 & 30.19 & 34.33 \\
\hline
\end{tabular}

Table 4 Significance of difference in hop yield variability between hop varieties determined by the t-test

\begin{tabular}{|c|c|c|c|c|c|c|c|c|c|c|c|c|}
\hline Variety & Bor & & & & & & & & & & & \\
\hline Saaz Late & - & S L & & & & & & & & & & \\
\hline Saaz & - & - & S & & & & & & & & & \\
\hline Sládek & - & - & - & $\mathrm{SI}$ & & & & & & & & \\
\hline Boomerang & - & - & - & - & B & & & & & & & \\
\hline Vital & - & 0.1 & - & - & - & v & & & & & & \\
\hline Kazbek & 0.1 & 0.1 & 0.1 & - & - & - & $\bar{K}$ & & & & & \\
\hline Bohemie & 0.05 & 0.1 & 0.1 & - & - & - & - & B & & & & \\
\hline Harmonie & 0.1 & 0.1 & 0.1 & 0.1 & - & - & - & - & $\mathrm{H}$ & & & \\
\hline Rubín & 0.01 & 0.1 & 0.05 & 0.1 & - & - & - & - & - & $\mathbf{R}$ & & \\
\hline Premiant & 0.05 & 0.1 & 0.1 & 0.1 & - & - & - & - & - & - & $\mathrm{P}$ & \\
\hline Agnus & 0.05 & 0.01 & 0.05 & 0.05 & - & - & - & - & - & - & - & A \\
\hline Gaia & 0.05 & 0.05 & 0.01 & 0.01 & 0.05 & 0.05 & 0.05 & 0.05 & 0.05 & 0.05 & 0.05 & 0.05 \\
\hline
\end{tabular}

The achieved results can be compared to foreign varieties that are also being tested in the conditions of the Czech Republic (genetic resources of hops). In the years 2014-2018, Nesvadba and Charvatova (2019b) evaluated the performance of selected foreign hop varieties as part of hop breeding aimed at resistance to Verticillium nonalfalfae. With the hop yields ranging between 0.96 $\mathrm{kg} /$ plant (Bramling Cross) and $3.35 \mathrm{~kg} /$ plant (Pilgrim), the results are slightly different. Czech hop varieties have yields between $1.85 \mathrm{~kg} /$ plant (Saaz) and $3.17 \mathrm{~kg} /$ plant (Gaia). As for the evaluation of hop yield variability, the range is higher, i.e. from $15.87 \%$ (Pioneer) to $51.39 \%$ (Pilgrim). The variability of Czech hop varieties is between $20.56 \%$ (Bor) and $34.33 \%$ (Gaia). It is evident from the results that some foreign hop varieties are not suitable for the conditions in the Czech Republic because they have a hop yield variability above $40 \%$ (Pilgrim, Pilot and Aurora).

Gaia has the highest content of alpha acids $-12.30 \%$ (Table 5 and Table 6). Vital, Boomerang and Rubín have an alpha acid content above $10 \%$. Their content of alpha acids is clearly higher than that of other hop varieties. Saaz and Saaz late have the lowest alpha acid content (3.06\% and $3.42 \%$, respectively). Statistical significance was not confirmed between Bor-Premiant, Kazbek-Bohemie and Saaz Late. Among hop varieties tolerant to Verticillium nonalfalfae, Vital has a considerably higher content of alpha acids than the tolerant Agnus, Sládek and Kazbek varieties. 
Table 5 Average content of alpha acids (\% w/w) in hop varieties in the years 2014-2019

\begin{tabular}{|c|c|c|c|c|c|c|c|}
\hline Variety & 2014 & 2015 & 2016 & 2017 & 2018 & 2019 & Average \\
\hline Gaia & 9.96 & 13.67 & 13.56 & 11.52 & 12.52 & 12.57 & 12.30 \\
\hline Vital & 9.67 & 13.17 & 10.25 & 10.27 & 11.09 & 12.08 & 11.09 \\
\hline Boomerang & 10.15 & 11.44 & 10.52 & 10.36 & 9.68 & 12.70 & 10.81 \\
\hline Rubín & 11.17 & 10.69 & 10.43 & 10.64 & 8.24 & 10.28 & 10.24 \\
\hline Agnus & 8.40 & 10.44 & 7.48 & 8.84 & 9.09 & 10.30 & 9.09 \\
\hline Bor & 8.96 & 7.02 & 9.01 & 8.23 & 6.39 & 7.79 & 7.90 \\
\hline Premiant & 6.89 & 8.05 & 7.00 & 8.34 & 5.62 & 7.87 & 7.29 \\
\hline Harmonie & 7.09 & 6.94 & 6.68 & 7.44 & 5.34 & 6.57 & 6.68 \\
\hline Sládek & 5.50 & 6.02 & 5.88 & 5.93 & 4.45 & 5.50 & 5.54 \\
\hline Kazbek & 4.31 & 6.57 & 4.43 & 4.88 & 4.39 & 4.61 & 4.86 \\
\hline Bohemie & 3.97 & 6.38 & 4.07 & 5.26 & 4.21 & 4.98 & 4.81 \\
\hline Saaz Late & 3.82 & 3.06 & 3.90 & 4.37 & 2.42 & 2.95 & 3.42 \\
\hline Saaz & 2.90 & 3.28 & 2.40 & 2.82 & 3.14 & 3.80 & 3.06 \\
\hline
\end{tabular}

Table 6 Significance of difference in alpha acid content between hop varieties determined by the t-test

\begin{tabular}{|c|c|c|c|c|c|c|c|c|c|c|c|c|}
\hline Variety & Gaia & & & & & & & & & & & \\
\hline Vital & 0.05 & V & & & & & & & & & & \\
\hline Boomerang & 0.05 & - & B & & & & & & & & & \\
\hline Rubín & 0.05 & - & - & $\mathbf{R}$ & & & & & & & & \\
\hline Agnus & 0.01 & 0.01 & 0.01 & 0.1 & A & & & & & & & \\
\hline Bor & 0.01 & 0.01 & 0.01 & 0.01 & 0.1 & B & & & & & & \\
\hline Premiant & 0.01 & 0.01 & 0.01 & 0.01 & 0.01 & - & $\mathbf{P}$ & & & & & \\
\hline Harmonie & 0.01 & 0.01 & 0.01 & 0.01 & 0.05 & 0.01 & 0.05 & $\mathrm{H}$ & & & & \\
\hline Sládek & 0.01 & 0.01 & 0.01 & 0.01 & 0.01 & 0.01 & 0.01 & 0.01 & s & & & \\
\hline Kazbek & 0.01 & 0.01 & 0.01 & 0.01 & 0.01 & 0.01 & 0.01 & 0.01 & 0.05 & K & & \\
\hline Bohemie & 0.01 & 0.01 & 0.01 & 0.01 & 0.01 & 0.01 & 0.01 & 0.01 & 0.05 & - & B & \\
\hline Saaz Late & 0.01 & 0.01 & 0.01 & 0.01 & 0.01 & 0.01 & 0.01 & 0.01 & 0.01 & 0.05 & 0.05 & S L \\
\hline Saaz & 0.01 & 0.01 & 0.01 & 0.01 & 0.01 & 0.01 & 0.01 & 0.01 & 0.01 & 0.01 & 0.01 & - \\
\hline
\end{tabular}

The variability of alpha acid content in Czech hop varieties is lower than their hop yield variability. This means that the former characteristic is influenced more by genetics than the environment. Rubín has certainly the lowest variability (4.28\%) (Table 8). The results show that Vital, Gaia, Boomerang and Bohemie have a very low variability. The undoubtedly highest variability was found in the group of hop varieties consisting of Saaz Late, Premiant, Agnus, Saaz, Kazbek, Bor and Harmonie. Among hop varieties tolerant to Verticillium nonalfalfae,
Vital has a noticeably lower variability of alpha acid content than Sládek, Agnus and Kazbek.

The results published by Nesvadba and Charvatova (2019b) show that foreign hop varieties have a considerably higher variability of alpha acid content, ranging from $12.48 \%$ (Target) to $46.86 \%$ (Bobek). It is evident from the results that hop varieties with a variability higher than 20\% (Bramling Cross, Savinsky Golding, Aurora, Bobek, First Gold, Pilot, Cascade, Phoenix and Pilgrim) are not suitable for growing in the Czech Republic. 
Table 7 Average variability (\%) of alpha acid content measured by CV (lead conductance value) in the years 2014-2019

\begin{tabular}{|c|c|c|c|c|c|c|c|}
\hline Variety & 2014 & 2015 & 2016 & 2017 & 2018 & 2019 & Average \\
\hline Rubín & 6.10 & 4.69 & 3.37 & 5.49 & 2.95 & 3.09 & 4.28 \\
\hline Vital & 5.02 & 5.46 & 8.56 & 6.50 & 3.74 & 4.51 & 5.63 \\
\hline Gaia & 6.55 & 3.77 & 5.19 & 5.17 & 5.10 & 8.54 & 5.72 \\
\hline Boomerang & 6.44 & 6.77 & 6.56 & 7.38 & 4.16 & 4.74 & 6.01 \\
\hline Bohemie & 8.36 & 6.18 & 5.39 & 6.55 & 7.33 & 7.17 & 6.83 \\
\hline Sládek & 6.98 & 7.06 & 7.44 & 8.24 & 5.18 & 9.79 & 7.45 \\
\hline Saaz Late & 10.09 & 6.22 & 4.51 & 6.26 & 15.39 & 5.62 & 8.01 \\
\hline Premiant & 11.02 & 10.75 & 6.86 & 6.91 & 6.68 & 6.51 & 8.12 \\
\hline Agnus & 9.68 & 6.97 & 8.40 & 8.36 & 6.17 & 11.70 & 8.55 \\
\hline Saaz & 10.84 & 9.35 & 9.42 & 8.20 & 5.20 & 13.72 & 9.45 \\
\hline Kazbek & 12.87 & 6.77 & 8.28 & 14.56 & 6.52 & 8.50 & 9.58 \\
\hline Bor & 6.50 & 10.60 & 10.06 & 10.63 & 14.54 & 8.01 & 10.06 \\
\hline Harmonie & 10.61 & 8.95 & 9.47 & 6.82 & 12.14 & 13.25 & 10.21 \\
\hline
\end{tabular}

Table 8 Significance of difference in the variability of alpha acid content measured by CV (lead conductance value) as determined by the t-test

\begin{tabular}{|c|c|c|c|c|c|c|c|c|c|c|c|c|}
\hline Variety & Rubín & & & & & & & & & & & \\
\hline Vital & 0.1 & V & & & & & & & & & & \\
\hline Gaia & 0.1 & - & G & & & & & & & & & \\
\hline Boomerang & 0.01 & - & - & $\bar{B}$ & & & & & & & & \\
\hline Bohemie & 0.01 & - & 0.1 & - & Boh & & & & & & & \\
\hline Sládek & 0.01 & 0.05 & 0.05 & 0.1 & - & $\mathrm{s}$ & & & & & & \\
\hline Saaz Late & 0.01 & 0.05 & 0.05 & 0.05 & 0.1 & - & $S \mathrm{~L}$ & & & & & \\
\hline Premiant & 0.01 & 0.05 & 0.05 & 0.05 & 0.1 & - & - & $P$ & & & & \\
\hline Agnus & 0.01 & 0.05 & 0.01 & 0.05 & 0.05 & 0.05 & - & - & A & & & \\
\hline Saaz & 0.01 & 0.05 & 0.01 & 0.05 & 0.05 & 0.05 & - & - & - & $\mathrm{S}$ & & \\
\hline Kazbek & 0.01 & 0.05 & 0.05 & 0.05 & 0.05 & 0.1 & - & - & - & - & K & \\
\hline Bor & 0.01 & 0.05 & 0.05 & 0.05 & 0.05 & 0.1 & - & - & - & - & - & B \\
\hline Harmonie & 0.01 & 0.05 & 0.01 & 0.05 & 0.01 & 0.05 & - & - & - & - & - & - \\
\hline
\end{tabular}

\section{Conclusion}

The achieved results show that both performance and performance stability are key indicators. Gaia has the highest hop yield but also the highest variability of yield. The yield ranges from 1.96 to $2.96 \mathrm{t} / \mathrm{ha}$. Bor shows the lowest hop yield. However it is more stable, ranging between 1.80 and 2.40t/ha. The highest hop yield stability was found in the Bor, Saaz Late, Saaz, Sládek, Boomerang and Vital varieties. The type of hop variety determines the content of alpha bitter acids. Naturally, the Gaia, Vital, Boomerang, Rubín and Agnus bittering hops have a higher content than aroma hops. A higher stability of the alpha acid content is preferable. The highest stability was found in the Rubín, Vital, Gaia, Boomerang and Bohemie varieties. Vital had the best overall evaluation. The achieved results are very important for hop growers and hop traders. Variability results are very important when it comes to the performance stability of Czech hop varieties.

The results are also important in terms of resistance to Verticillium nonalfalfae. The first tests suggest that the Agnus, Vital and Sládek varieties have a medium tolerance. All three varieties show a medium stability of hop yield and alpha acid content. All of the hop varieties are suitable for inclusion in a breeding program aimed at resistance to Verticillium nonalfalfae. Kazbek shows a medium resistance but a higher variability of the content of alpha acids. 


\section{Acknowledgement}

This article was written as part of project NAZV QK21010136 entitled Application of new hop varieties and genotypes resistant to drought in hop growing and beer brewing with the financial support of the Ministry of Agriculture.

\section{References}

Čerenak, A., Radišek, S., Košir, I.J., Oset Luskar, M., Kolenc, Z., Jakše, J., Javornik, B. (2015). Recent Advances in Slovenian Hop Breeding. In: Book of Abstracts. Yakima: USA, IV. Internation. Humulus Symp., 2015: 42.

Fric, V. (1992). Odrůdová skladba a ozdravovací proces chmele v ČSFR (eng. Varietal composition and healing process of hops in the Czech-oslovak Socialist Republic). Chmelařství 11, 85-86.

Krofta, K. (2008). Hodnocení kvality chmele: Metodika pro praxi 4/2008. (eng. Evaluation of hop quality: Methodology for practice 4/2008.) Hop Research Institute, Ltd., Žatec, 52 pp. ISBN 978-80-86836-843 Available in Czech from: https://invenio.nusl.cz/record/170477/ files/nusl-170477_1.pdf

Krofta, K., Patzak, J., Nesvadba, V., Mikyška, A., Slabý, M., Čejka, P. (2013). Vital - The Czech hop Hybrid variety. Kvasný průmysl, 59(1), 13-17. https://doi.org/10.18832/kp2013001

Nesvadba, V., Krofta, K., (2002). New hop variety Agnus as the result of breeding process innovation in the Czech Republic. Rostlinná výroba, 48(11), 513-517.
Nesvadba, V., Brynda, M., Henychová, A., Ježek, J., Kořen, J., Krofta, K., Malíŕová, I., Patzak, J., Polončíková, Z., Svoboda, P., Valeš, V., Vostřel, J. (2013). Development and tradition of Czech hop varieties. Hop Research Institute, CO., LTD., Žatec, $91 \mathrm{pp}$

Nesvadba, V. (2016). Breeding Process Aimed at Dwarf Hops. Kvasný průmysl, 62(6), 166-172. https://doi.org/10.18832/kp2016022

Nesvadba, V., Charvátová, J., Štefanová, L. (2017). New Varieties and Perspective Genotypes of Hops. Kvasný průmysl, 63(5), 237-240. https://doi.org/10.18832/kp201724

Nesvadba, V., Charvátová, J., Štefanová, L. (2019a). Breeding of aroma hops in the Czech Republic. In: F. Weihrauch, ed. Proceedings of the Scientific-Technical Commission 07 - 11 July 2019, Bischoffsheim, France. Wolnzach: Scientific-Technical Commission of the International Hop Growers' Convention. 16-18.

Nesvadba, V., Charvátová, J. (2019b). Hodnocení výkonnosti a variability odrůd chmele s tolerancí k Verticillium nonalfalfae (eng. Evaluation of productivity and variability of hop varieties with the tolerance to Verticillium nonalfalfae). Úroda, 11, 78-81.

Nesvadba, V., Charvátová, J. (2020). Nové odrůdy chmele registrované v roce 2019 (eng. New hop varieties registered in 2019). Sborník přednášek a příspěvků ze semináře Agrotechnika chmele konaného 20.02. 2020. 163-171. ISBN 978-80-86836-40-9.

Patzak, J., Henychová, A. (2018). Evaluation of genetic variability within actual hop (Humulus lupulus L.) cultivars by enlarged set of molecular markers. Czech Journal of Genetics and Plant Breeding, 54(2), 86-91. https://doi.org/10.17221/175/2016-CJGPB

Svoboda, P., Malířová, I. (2013). Assessment of ApMV and HMV presence in recovered Saaz. Proceedings of Scientific Commission of IHGC, Kiev, Ukraine, June 4-9. pp. 61. 